\title{
Migrated hydrocarbons in basalt on the south side of Scoresby Sund
}

\author{
W. Stuart Watt and Per Wrang
}

A tar-like material was found in a fault zone affecting basalt on Savoia Halvø. The material is totally biodegraded but analyses indicate that it is from a raw oil.

\section{Local setting}

The sample was obtained from a basalt block belonging to formation 3 of Watt \& Watt (1983) in a fault gash approximately $500 \mathrm{~m}$ altitude above the east side of Kamelgletscher $\left(70^{\circ} 3.5^{\prime} \mathrm{N}, 22^{\circ} 28.4^{\prime} \mathrm{W}\right)$. The fault is part of the extensive coast-parallel suite of faults (Watt, 1975) where it crosses Savoia Halvø. The fault suite has a total downthrow of more than 2000 $\mathrm{m}$ to the SE displacing sediments of Miocene Age (Kap Brewster Formation). At the sample site a local fault has a downthrow to the NW of 400 to $500 \mathrm{~m}$.

\section{Regional geological setting}

North of Scoresby Sund the Jameson Land sedimentary basin contains more than $2500 \mathrm{~m}$ of Mesozoic sediments which thin and dip gently southwards (Birkelund \& Perch-Nielsen, 1976). The southward extent of this basin cannot be delimited since basalts of uppermost Paleocene to Lower Eocene Age completely cover the region south of Scoresby Sund. Only at the huts at Kap Brewster are there a few square metre outcrops of black mudstones of Upper Cretaceous Age (R.A. Fensome, personal communication, 1980). This, together with the presence of the bitumen sample reported here and the presence of methane in the warm springs in the basalts at Rømer Fjord (Watt, unpublished data; Halliday et al.,1974) 50 $\mathrm{km}$ to the south suggest that the Jameson Land sedimentary basin continues southwards beneath the basalts. Migrated hydrocarbons are known in the Upper Permian and Lower Triassic in northern Jameson Land (Surlyk et al., 1984).

\section{Bitumen sample}

The material (GGU 215848) lay as a loose block $(2 \times 1 \times 1 \mathrm{~m})$ embedded in scree in the fault gash with the black, tarry substance on the lower? surface of the block. Although loose it is clearly of local origin in the fault plane. A freshly fractured surface showed black material oozing from the pore spaces in the basalt. The locality is well away from all human activity and the tarry surface lay in an unlikely position for contamination from an oil spill from a helicopter or from any type of motor.

The black substance was extracted in the laboratory and analysed by gas chromatography and mass spectrometry. The analysis indicated extensive biodegradation with only traces of $n$-alkanes and there is nothing to indicate a derivation from any type of refined oil. The sample is a surface sample that has been affected by water washing which may be why it is only preserved on the lower surface of the block. The material is therefore thought to have 
migrated along the fault plane over a minimum distance of $800 \mathrm{~m}$ which is the estimated depth to the bottom of the basalts. Because of the biodegradation there is no indication of the nature of the source of the material. However, both the Upper Permian Posidonia Shale and Upper Jurassic Hareelv Formation are known to have source rock potential in the Jameson Land basin, and a southwards extension of these could well have produced these hydrocarbons (Surlyk et al., 1984). The existence of other source rocks beneath the basalts cannot be excluded.

\title{
References
}

Birkelund, T. \& Perch-Nielsen, K. 1976: Late Palaeozoic - Mesozoic evolution of central East Greenland. In Escher. A. \& Watt, W. S. (edit.) Geology of Greenland, 304-339. Copenhagen: Geol. Surv. Greenland.

Halliday, G., Kliim-Nielsen, L. \& Smart, I. H. M. 1974: Studies on the flora of the northern Blosseville Kyst and on the hot springs of Greenland. Meddr Grønland 199 (2), 49 pp.

Surlyk, F., Hurst, J. M., Marcussen, C., Piasecki, S., Rolle, F., Scholle, P. A., Stemmerik, L. \& Thomsen, E. 1984: Oil geological studies in the Jameson Land basin, East Greenland. Rapp. Grønlands geol. Unders. 120, this report.

Watt, M. 1975: Photo-reconnaissance of the Blosseville Kyst between Steward Ø and Søkongens Bugt, central East Greenland. Rapp. Grønlands geol. Unders. 75, 91-95.

Watt, W. S. \& Watt, M. 1983: Stratigraphy of the basalts of Savoia Halvø, central East Greenland. Rapp. Grønlands geol. Unders. 115, 83-88.

\section{Oil geological studies in the Jameson Land basin, East Greenland}

\author{
F. Surlyk, J. M. Hurst, C. Marcussen, S. Piasecki, F. Rolle, P. A. Scholle, \\ L. Stemmerik and E. Thomsen
}

An oil geological project was started in Jameson Land in 1982 (Surlyk, 1983; Surlyk et al., in press). The field work part of the project was completed in 1983. A major source rock programme, focusing on the evaluation of potential onshore and offshore source rocks, is central to the project.

The technical personnel J. Boserup, A. Clausen and K. Villadsen worked on the shallow core drilling crew, whilst E. Thomsen, S. Piasecki, C. Marcussen, F. Rolle and F. Surlyk alternated as well-site geologists. In 1983 a total of nine holes were drilled mainly to depths of about $30 \mathrm{~m}$ (fig. 36). One hole was drilled in Upper Permian bioturbated siltstone at Domkirken south of Mestersvig (1, fig. 36); one in Upper Permian carbonate and black shale at Rødstaken, eastern side of Schuchert Dal (2, fig. 36); one in Upper Permian carbonate at Revdal (3, fig. 36), and one in Upper Permian limestone and black shale in the southern part of Karstryggen, western side of Schuchert Dal (9, fig. 36); two in Devondal, 